\title{
Sites of Controversy: Jews Debating Philosophy between Iberia and Occitania in the Fourteenth Century
}

\author{
Tamar Ron Marvin \\ Hebrew Union College-JIR, Los Angeles \\ trmarvin@gmail.com
}

\begin{abstract}
The extant sources of the Maimonidean controversies demonstrate that medieval Jewish intellectual culture was fundamentally sited in actual encounters and interactions. Such interactions often took place around the practices of writing, conveying, receiving, and discussing letters, social activities governed by communal norms. Whether in the course of collaborating with co-writers, seeking signatories in support of a proposition contained in the letter text, or congregating at an established meeting to discuss a newly arrived letter, those involved in the controversies were actively, socially engaged in addressing the problems raised by the incompatibility of the GrecoIslamic rationalist tradition with rabbinic principles. Through a careful examination of the rich letter collection Minhat Qena'ot from the Maimonidean controversy of 13041306, this paper details the modes of encounter among discussants in the acrimonious cultural debate.
\end{abstract}

\section{Keywords}

Maimonidean Controversy - Occitania - Jewish philosophy - letters

The Jewish "encounter" with Aristotle in the Middle Ages, mediated through a variety of transmitters and interpreters, refers to the reception, interaction, and reworking of rationalist ideas of Greco-Islamic origin into rabbinic modes of thought. This metaphorical encounter, however, is necessarily made up of actual, physical encounters: between translators and the texts from which they worked, as well as the texts' owners or purveyors; among intellectuals 
discussing ideas; between teacher and pupil, sermonizer and audience, textual object and reader. The unusual compilation Minhat Qena'ot, edited by Abba-Mari b. Moses ha-Yarhi, c. 1307, provides a rare opportunity to assess evidence of just such encounters in the course of the acrimonious public debate over the role rationalist philosophy was to play in Jewish intellectual culture. ${ }^{1}$ Preserved in Minhat Qena'ot are records of public sermons and speeches as well as closed-door meetings of community leaders. It thus reflects the many roles which letters played in the life of the community and in the debate over philosophy.

The matter in question is one of a series of intra-communal debates termed "the Maimonidean controversies," which began some one hundred and twenty years earlier during the lifetime of Moses Maimonides (Rambam, c. 1138-1204). Maimonides was the preeminent agent of the integration of Aristotelianism with traditional Jewish thought. While this process began earlier in the medieval period, it reached a critical mass of dissemination and influence in Maimonides' works, especially in in his Mishnah commentary, the Sirāj; his introduction to the legal code Mishneh Torah, titled Sefer ha-Madda'; and in the treatise Moreh ha-Nevukhim (Dalālat al-Hä̉irinn). Before then, rabbinic Jewish thought, the substrate of medieval Jewish thought, theorized discrete exegetical and legal topics without providing a conceptual framework for the legal system. For this reason, the very act of imposing such a systematic conceptualization upon halakhah (Jewish law) was an external process, and was criticized as such. In other words, the development of a Jewish theology, and

1 Minhat Qena'ot has been printed in two editions in the modern era, once in Pressburg (Bratislava) in 1838 by Mordecai Leib Bisliches (under the approbation of the Hatam Sofer) and again in Jerusalem in 1991, edited, annotated, and with a critical apparatus by H. Z. Dimitrovsky. The Pressburg text has been reprinted in whole or in part several times and is based upon a lost manuscript; Dimitrivsky's apparatus includes all eight extant manuscripts. Here, the Pressburg edition is abbreviated MQp, and the Dimitrovsky edition MQd. References are given as edition, chapter, page number and, for MQd, line numbers. Unless otherwise noted, my translation follows Dimitrovsky's critical text.

The evidence found within the text indicates that Abba-Mari likely edited Minhat Qena'ot in 1307 , possibly in Perpignan. On the letters which bear headnotes clearly authored by Abba-Mari, the latest given date is 'ehad bi-Shevat in the year sheva' li-ferat, i.e., 1 Shevat $(=5$ January) 1307 , in MQp 100, p. 179 / MQd 120 (b), p. 836, l. 12, with reference to ll. $5^{-6}$. This is the date on which, Abba-Mari reports, he reached Perpignan from Arles in the fourth month of his exile from Montpellier, although it is not clear that he was allowed to settle there. All the letters authored by Abba-Mari which occur after this letter (MQp 100 / MQd 120[b]), in those manuscripts which contain them, appear to have been included by a later editor, since they bear headnotes that mention Abba-Mari in the third person. This points to a terminus ad quem of 1307 for Abba-Mari's active editorial work on Minhat Qena'ot. 
in particular a theory of halakhah, was prompted through contact with GrecoIslamic rationalism.

This harmonization was not without its opponents, though their criticisms and motivations varied significantly according to time and place, with public debates breaking out from North Africa to northern France, Iberia to the Middle East. The most frequent site of controversy over the course of the thirteenth century and into the early fourteenth was Occitania, spilling over to the neighboring community of Catalonia. It was there that much of the philosophical achievements of the Judeo-Arabic synthesis were first translated into Hebrew for popular consumption, fueled by émigrés fleeing persecutory movements and wartime conquests in Iberia. As a result, the intellectual movement termed "Maimonideanism" flourished in Occitania. ${ }^{2}$ By the time of the 1304 controversy, the validity and value of Greco-Islamic rationalism was well-established and was not the major concern raised by controversialists. In fact, Abba-Mari, who instigated the debate by reaching out to the giant of the age, decisor Abraham b. Adret of Barcelona (Rashba, c. 1235-c. 1310), was himself a pedigreed intellectual who wrote philosophical treatises. The question, instead, became: How can philosophy be used responsibly?

Abba-Mari, Ibn Adret, and their supporters suggested a solution using the old legal tactic of the ban, and based upon the traditional principle of induction into mystical studies — that is, advanced, sensitive material — only past the age of forty. According to their ban proposal, philosophy was only to be studied by, or taught to, those over the age of twenty-five. ${ }^{3}$ The measure passed handily in Ibn Adret's Barcelona, but was subject to bitter controversy in Montpellier. However, it was, ultimately, halted by the 1306 expulsion of Jews from France (and various territories under the influence of the French Crown, including Montpellier).

The latter "Maimonidean controversies" were sited in two kinds of spaces: the space of the written text and the physical meeting between two or more

2 James T. Robinson has suggested that this integration of rationalism was achieved by means of "the development of a Maimonidean tradition of biblical commentary; the development of a Maimonidean method of exegesis; and the creation of a philosophical library in Hebrew to support the reading of the Guide of the Perplexed." He calls the "clearly defined philosophical-literary movement" created by this integration process Maimonideanism, and points out that thirteenth-century Occitania represents the first such development. See his "We Drink Only from the Master's Water: Maimonides and Maimonideanism in Southern France, 12001306," Studia Rosenthaliana 40 (2008): 27-6o; and the introduction to idem, ed., The Cultures of Maimonideanism: New Approaches to the History of Jewish Thought (Leiden: Brill, 2009).

3 Ban proponents initially lobbied for a minimum age of thirty, but eventually moderated their proposal: MQp 70, p. 141 / MQd 89, pp. 696-697, ll. 7-12.; MQp 73, p. 143 / MQd 92, p. 701, ll. 6-7; MQp 62, p. 134 / MQd 81, p. 675, l. 17. 
individuals. Often, indeed, these two sites overlapped in meetings convened around the reading, writing, discussion of letters, and the approbation of or opposition to their contents. Letters, as public, written communications, were not disembodied texts but physical objects, the handling of which was carefully controlled by their authors and the messengers whom they selected for their conveyance. Letters were also protected by halakhic principles, notably hezqat shaliah, "possession of the messenger," intended to guarantee the integrity of letters by empowering their conveyor to enforce the exclusivity or publicity of the intended recipients. ${ }^{4}$

The many points of contact occasioned by the conveyance of a letter are exemplified by the case of a highly sensitive letter dispatched by Ibn Adret to the Montpellier qahal (community). Ibn Adret selected a trusted pupil to act as his messenger, the up-and-comer Mordecai, whom he instructed to deliver the letter to Abba-Mari and Todros de Bilqieri ("of Beaucaire," fl. c. 130o). Abba-Mari and Todros were to feel out the potential response before reading it to the entire community assembled for Shabbat services. If Abba-Mari and Todros felt that its contents were unacceptable to the community, they were to conceal the letter on the instructions of Barcelona. ${ }^{5}$ Ibn Adret was right to proceed cautiously, as the contents of the letter did indeed set off a firestorm of controversy. Abba-Mari would effusively apologize to Barcelona; it may well be that Abba-Mari's judgment at this juncture did not match Ibn Adret's intentions, and that he miscalculated in releasing the contents of the letter. ${ }^{6}$

Perhaps because of the sensitivity of the situation and the outcry it engendered, in writing the editorial note to the letter months or years later, AbbaMari emphasizes the care with which he obtained access to the letter and the punctiliousness with which Mordecai delivered it. Specifically, Abba-Mari is at pains to point out that Mordecai's mission is, halakhically speaking, already assumed to be complete at the time he arrived at Abba-Mari's doorstep (under the principle hezqat shaliaḥ 'oseh shelihuto mentioned above). He also underscores that although Mordecai had conveyed the permission of the Barcelona beit din for them to read it first, nevertheless he and Todros "pulled back our

4 On hezqat shaliah 'oseh shelihuto, see Eiruvin 31b, Isaac b. Jacob al-Fasi (Rif, 1013-1103) to Shabbat 47 b, and Asher b. Yehiel (Rosh, c. 1250-1327) to Eiruvin 3:3, and cf. Bava' Qama' 113a. On medieval Jewish messengering and authorial control, see Ram Ben-Shalom, "Communication and Propaganda Between Provence and Spain: The Controversy over Extreme Allegorization (1303-1306)," in Communication in the Jewish Diaspora: The PreModern World, ed. Sophia Menache (Leiden: Brill, 1996), 171-225; and Tamar Ron Marvin, "The Making of Minhat Qena'ot: The Controversy over Ideational Transgression in FourteenthCentury Jewish Occitania" (Ph.D. diss., Jewish Theological Seminary, 2013), 86-92.

5 MQp 21, p. 6o / MQd 39, p. 415, ll. 1-15.

6 MQp 25, pp. 68-70 / MQd 44, pp. 440-4 and MQp 26, pp. 70-71 /MQd 45, pp. 444-8. 
hands from opening the letter until the messenger [Mordecai] opened it himself, and [only] then did we read it out and punctiliously consider the words of the letter." ${ }^{7}$ Why the hesitation? Todros and Abba-Mari were faced with an ethically ambiguous situation: although Mordecai had oral instruction to allow them to unseal and read the letter prior to the communal gathering, its proper "addressee" was the entire qahal. Ram Ben-Shalom suggests that Abba-Mari and Todros "were very sensitive to the ethics of their opening a letter addressed to the entire community; although from a halakhic standpoint the verbal message carried by the messenger was tantamount to permission to open the letter, the two refused to open it themselves, and the messenger eventually opened it for them."8 Although there was a great deal of potential benefit to be derived from opening the letter, and although they had the halakhic imperative and explicit permission to do so, Abba-Mari is interested in portraying himself and Todros as taking every precaution to handle the matter appropriately and fairly. What made their action appropriate was that they waited (practically sitting on their hands, it would seem) until the messenger "authenticated" their access by unsealing the letter himself. They then read it together. Both the care Abba-Mari takes in relaying these events and the explicitness of the instructions given to Mordecai demonstrate the degree to which letters were living documents used in real ways, under the mediation of a messenger.

Once a letter to a community arrived, it was often the occasion for a private or public gathering, typically involving a public reading. Such meetings might take place in communal spaces such as synagogues, batei din (courts of law), and batei midrash or yeshivot (study centers); or in homes or other private spaces, when meetings were held among individuals or small groups. Several interesting and significant letters in Minhat Qena'ot record both types of gatherings, public meetings as well as personal encounters, which allow us to see how ideas were actively discussed by at least a portion of the educated elite in Montpellier. Publicly convened readings of other types of texts are also evidenced in Minhat Qena'ot, including legislative proposals, enacted legislation, sermons, and philosophical materials.

For instance, Abba-Mari notes in one letter that he had hired a messenger to announce a communal meeting of unspecified location: "I commanded the messenger to call all the gentlemen (nikhbadim), who are known as meyuhadim, to attend a meeting of the leaders of the community."9 On another occasion,

7 MQp 21, p. 6 o / MQd 39, p. 415, ll. 5-8.

8 Ben-Shalom, “Communication and Propaganda," 192. This is also Dimitrovsky's view; see p. 415, n. 6 .

9 MQp 21, p. 62 / MQd 39, p. 418, 1l. 53-54. Note that in this context, nikhbad, which I have rendered "aristocrat," is not a distinct term of nobility; rather, it broadly connotes a member of high standing in the community. 
upon receiving an important letter from the Barcelona leaders, Abba-Mari reports that he and Todros de Bilqieri "appointed a time on Shabbat in the month of Elul in the year 1304, on which to hold a meeting of the communal leaders in the synagogue for the purpose of reading the letter so that they may hear it."10 This meeting proved a pivotal event in the course of the controversy, during which Jacob b. Makhir (Don Profet Tibbon de Marseilles/Profatius Judaeus, c. 1236-1306), a member of the famed Ibn Tibbon translator family, defended the Occitan rationalist tradition and garnered the support of a faction ('agudah) of the assembled community.

This was not unique to Montpellier and seems to have been at least a regional, if not broader, practice. Elsewhere in Minhat Qena'ot, Ibn Adret reports that he brought the text of the ban before the Barcelona qahal, which accepted it in a community meeting that took place on the Shabbat of Parashat Devarim (31 July 1305). ${ }^{11}$ These practices accord with what is known about non-sacral uses of synagogue space from other sources. ${ }^{12}$ S. D. Goitein summarizes the evidence of the Cairo genizah:

Since everything done by or for the "Holy Congregation" was hallowed with a religious connotation, the synagogue was also the proper place for attending to communal affairs. The letters of the ecumenical or territorial authorities or of other communities, near and far, were read out, discussed, and acted upon; resolutions proposed by the elders or by an individual leader were acclaimed or rejected; bans were pronounced and public chastisements, such as stripes, were administered; collections were solicited, vows for donations were made, and reports about public finances or other matters rendered during or immediately after the service or between prayers ... In short, all matters of public concern ... were normally transacted in the synagogue, in conformity with age-old, even pre-Christian usage ... and the Muslim house of worship, the mosque,

\footnotetext{
$10 \quad$ MQp 21, p. 60 / MQd 39, p. 415, ll. 13-15.

11 MQp 71, p. 141 / MQd 90, p. 599, ll. 13-16. In addition to the reading of the first communal letter from Barcelona, see MQp 33 / MQd 52.2; MQp 68 / MQd 87; and MQp 71 / MQd 90; MQp ps-88 / MQd 99.

12 That is, at least until the growth of urban communities in the later Middle Ages, when socially-stratified synagogues became more commonplace; see Yom Tov Assis, The Golden Age of Aragonese Jewry: Community and Society in the Crown of Aragon, 1213-1327 (London and Portland, Or.: Vallentine Mitchell, 1997), 213-15.
} 
was its counterpart. Special invitations to meet in the synagogue for deliberations on public affairs have been found in the genizah. ${ }^{13}$

More specifically, in fourteenth-century Occitania, Joseph Shatzmiller has described five instances of public quarrels breaking out in the synagogue of Manosque (in western Provence) following communal announcements between 1292 and 1338 , based on archival documents. ${ }^{14}$ He presents the Manosque synagogue as typical of those found in the region and period, which functioned as the "place where the members of the 'holy community' managed their communal affairs: levying taxation, enacting regulations and contracts, proclaiming excommunication and ostracizing individuals and groups." 15 Shatzmiller notes that Qalonymos b. Qalonymos (fl. c.) also describes the synagogue at Arles c. 1300 as a place of social meeting and dissention. ${ }^{16}$ Public letters, then, were usable documents: they were read aloud, talked about, copied, and considered in governance; and meetings convened around them were a significant

13 S. D. Goitein, Mediterranean Society: The Jewish Comunities of the World as Portrayed in the Documents of the Cairo Geniza, 6 vols. (Berkeley and Los Angeles: University of California Press, 1999), 2:165.

14 Joseph Shatzmiller, "Tumultus et Rumor in Sinagoga: An Aspect of Social Life of Provençal Jews in the Middle Ages," Association of Jewish Studies Review 2 (1977): 227-55. See also Bernard Septimus's reconstruction of synagogue interactions in "Piety and Power in Thirteenth-Century Catalonia," in Studies in Medieval Jewish History and Literature, ed. Isadore Twersky, 196-230 (Cambridge, Mass.: Harvard University Press, 1979), 199-201. An early description of rival factions competing for dominance by proxy of synagogue space is preserved in Kol-Bo no. 142 (Naples or Venice, 1491/2); English translation in Michael Walzer, et al., eds., The Jewish Political Tradition, Vol. 1: Authority (New Haven: Yale University Press, 200o), 392-396. Though the Kol-Bo is probably contemporaneous with Minhat Qena'ot and of Occitan provenance, the events described in no. 142 are likely much older. On the provenance of the first edition of the Kol-Bo, see Adriaan K. Offenberg, "The Dating of the Kol Bô: Water Marks and Hebrew Bibliography," Studia Rosenthaliana 6 (1972): 86-106, reprinted in his A Choice of Corals: Facets of 15th Century Hebrew Printing (Nieuwkoop, Netherlands: De Graaf, 1992), where he suggests that the book was most likely printed at Naples in 1491/2, though the evidence is inconclusive.

15 Shatzmiller, "Tumultus," 228.

16 Ibid., 233-8. The passage is in Qalonymos b. Qalonymos, 'Even Bohan, ed. A. M. Habermann (Tel Aviv, 1956), 23-29. Meanwhile, in Egypt, a responsum by the nagid, Joshua b. Abraham (II) Maimon (1310-1355), a great-great-grandson of Maimonides, requests within the text that it be read aloud after prayers (presumably Shaharit) on three consecutive days, Thursday through Shabbat. See Sophia Menache, "Communication in the Jewish Diaspora: A Survey," in Communication in the Jewish Diaspora, ed. ibid., ${ }^{5-56}$ (Leiden: Brill, 1996), 24; Mark R. Cohen, "Correspondence and Social Control in the Jewish Communities of the Islamic World: A Letter of the Nagid Joshua Maimonides," Jewish History 1-2 (1986): 39-48. 
event in the life of the community, a site of discussion, dissention, and civicpolitical action. ${ }^{17}$

The importance and efficacy of having letters to read aloud is illustrated by Ibn Adret's request to Abba-Mari that he collect and copy for him all the letters he could get a hold of concerning the ban. Such a was evidently intended as a reference for conducting a pro-ban campaign in Iberia. ${ }^{18}$ This request reached Abba-Mari just after Passover 1305, and, due to practical difficulties and his propensity for care in such an undertaking, he did not respond for some time. Sason b. Meir, one of Ibn Adret's leading pupils, subsequently wrote to AbbaMari urging him to hurry. ${ }^{19}$ In fact, Sason pointedly tells Abba-Mari that, as a student in Ibn Adret's beit midrash, he had access to the letters that arrived there. He himself had collected them over a period of six months, whereupon he traveled with them to his hometown of Tudela from Barcelona, circulating them among the community leaders. ${ }^{20}$ He reports that the Tudela aristocrats were dismayed by the events and asked Sason to relay their support of the ban to Ibn Adret: ${ }^{21}$

Six months ago I went to my birthplace, Tudela in Navarre, with all [your letters], as I presently live in Barcelona where I make my home; and I

17 MQp 21, p. 61 / MQd 39, p. 418-9, ll. 53-68.

18 MQp 66, p. 138 / MQd 85, p. 687, 1l. 31-34.

19 This individual's name is recorded as Samson rather than Sason in four of the manuscripts and in MQp, but the play on the word sason in MQp 69, p. 140 / MQd 88, p. 694, ll. 4-5, likely indicates that Sasson is correct. Abba-Mari writes to Ibn Adret that "your letter," most likely his preceding letter, MQp 66 / MQd 85, along with Sasson b. Meir's letter, arrived in Montpellier on the Friday of Parashat va-'Ananekha (Lev. 14:14, in Parashat Tazrica, read just after Passover), MQp 68, p. 139 / MQd 87, p. 691, ll. 11-15). In a subsequent letter (MQp 69, p. 140 / MQd 88, p. 696, ll. 27-29), Abba-Mari explains apologetically to Sasson that he is doing his best to have the letters copied per Ibn Adret's request, but that he does not possess all of them and he is attempting to collect them.

20 It seems that Sasson means here to tell Abba-Mari that his task is both important and not so difficult, something he should have gotten to already. Presumably, the letters in Sasson's possession did not include the letters that had been dispatched from Barcelona and where in the possession of Abba-Mari, which is why the Barcelona leadership required Abba-Mari's contribution.

21 MQp 67, p. 138 / MQd 86, pp. 688-689, 1l. 15-21. Sason may have been presenting a rosier picture of the unanimous support of the Tudela nikhbadim, considering that in 1305 a majority of those nikhbadim passed an ordinance stating that the Mishneh Torah would serve as the basis for their communal decision making; nor was this a unique occurrence; a variety of Iberian communities adopted the Mishneh Torah as the authoritative code of law during the thirteenth century (Assis, The Golden Age of Aragonese Jewry, 69). However, this is perhaps further evidence of the need for such a collection and its practical function. 
brought the letters with me and showed them to the communities and to the learned of the land. They were shocked by the matter and responded, asking me to tell our master that we are correct to ban and excommunicate according to all that he will permit. ${ }^{22}$

This was not Sasson's first such campaign; he reports that he had traveled for such a mission previously, in the controversy sparked by Solomon Petit c. 1290. Due to the success of these campaigns, Ibn Adret tasked Sasson with conducting them more widely:

He [Ibn Adret] asked me to do a good deed and be the messenger in this matter, just as I had done a good deed by being the messenger and traveling to Castile and Navarre and to all the rest of the communities on the matter of the nagid Rabbi David [Maimuni], the son of the Great Eagle, our master Moses [Maimonides] of blessed memory; and I collected on his behalf five thousand silver tournois [Tours pounds]. ${ }^{23}$

We also know Jacob b. Judah de undertook a campaign remarkably similar to Sasson's, traveling throughout Occitania to garner support for the ban. Jacob records that he went "from house to house, corner to corner, neighborhood to neighborhood," gathering support by his personal stature and persuasion as well as by showing the letters he carried to the residents. ${ }^{24}$ His campaign was successful: Abba-Mari eventually received signed letters of support from Argentière, Capestang, Aix, and Lunel. ${ }^{25}$ These included the letters of Abraham b. Joseph b. Abraham Barukh b. Nuriah of Aix and his son Joseph Samuel; from the nikhbadim of Argentière; from the nikhbadim of Lunel; and from Asher b. Yehiel (Rosh, c. 1250-1327) in Toledo.

Opponents of the ban used similar tactics to discuss and strengthen their positions. Shelemiah (or Solomon; both variations occur) b. Isaac b. AbbaMari "ha-Nesiah" (or "ha-Nasi") de Lunel spearheaded a public relations campaign against the passage of a ban by reading aloud Jacob Anatoli's Malmad ha-Talmidim, a book of rationalistic homiletical essays, after the afternoon Minhah prayers on Shabbat Parah (following the holiday of Purim). Shelemiah and his supporters pledged to do so every following Shabbat as well. ${ }^{26}$

\footnotetext{
22 MQp 67, p. 138 / MQd 86, pp. 788, 11. 8-12.

23 MQp 67, p. 138 / MQd 86, pp. 788-789, ll. 16-19. David Maimuni was the grandson of Maimonides, the son of Maimonides's son Abraham.

24 MQp 53, p. 115 / MQd 72, p. 696-697, ll. 179-80.

25 Jacob b. Judah describes his route in great detail, MQp 53, p. 115 / MQd 72, pp., ll. 156-70.

26 MQp 68, p. 139 / MQd 87, p. 692, ll. 39-42.
} 
According to Abba-Mari's account of the events, Shelemiah was under the impression that Abba-Mari was acting under orders from Barcelona to institute the ban, and spoke publicly against Abba-Mari in the synagogue on the day of Parashat Qorah (Num. 16:1-18:32, read in mid-June in that year). Shelemiah also informed the Anatoli family that Abba-Mari had been accusing Jacob of impropriety. ${ }^{27}$ The emphatic, public nature of the "protest reading" of Malmad ha-Talmidim indeed seems to have discouraged ban proponents, and Ibn Adret wrote impatiently to Qalonymos ha-Nasi, urging him to stop hesitating and institute the Montpellier ban. ${ }^{28}$

Hoping to galvanize pro-ban discussion, Abba-Mari composed Sefer haYare'ah, an essay (ketav) in fifteen chapters summarizing and solidifying the ideology underpinning the proponents' activities. Intended to be a reference for supporters of the ban in their public activities and, likely, a publicly circulated document, Sefer ha-Yareah has been aptly termed a "position paper" by Gregg Stern: "Abba Mari presents here his rationalist justification for the prohibition of philosophic study before physical and intellectual maturity."29 Though the essay is somewhat rarified in its subject matter, Abba-Mari apparently intended to bolster the pro-ban camp's somewhat flimsy ideological defense of their proposal, which relied upon propagandistic "slogans" such as the oft-repeated rhyme, "they made Abraham and Sarah into Matter and Form." ${ }^{30}$ In concise and direct chapters, he laid out an epistemological theory, based on well-established precedent within the Jewish philosophical tradition, suggesting that all knowledge, including rational knowledge, originated at Sinai and was possessed by the prophets, only to be lost in the exile of Israel from its land. ${ }^{31}$ In his treatise, it is Aristotle who is singled out for incorrect beliefsspecifically, his denial of God's knowledge of particulars - while Maimonides is defended and vindicated. Citing such thinkers as David Qimhi (Radaq, c. 1160-c. 1235), Samuel ha-Nagid (ha-Levi b. Joseph/Ismā'ìl b. Naghrīlah, 9931055/6), and Hai b. Sherira Ga'on (939-1038), Abba-Mari maintains that, on the one hand, well-trained minds are easily able to discard the proverbial chaff

\footnotetext{
27 MQp 68, p. 139 / MQd 87, p. 692, ll. 37-39.

28 MQp 71, pp. 141-2 / MQd 90, pp. 698-700.

29 Gregg Stern, "Menahem Ha-Me'iri and the Second Controversy over Philosophy" (Ph.D. diss., Harvard University, 1995), 138. See also his Philosophy and Rabbinic Culture: Jewish Interpretation and Controversy in Medieval Languedoc (New York: Routledge, 2008), 159-61.

$30 \quad$ For a detailed examination of this and other slogans, see Marvin, "The Making of Minhat Qena'ot," 222-35.

31 See Abraham Melamed, The Myth of the Jewish Origins of Science and Philosophy (Jerusalem: Magnes, 2010).
} 
from the wheat of foreign philosophy. On the other hand, he also contends that rationalist philosophy has the potential to cause transgression of Torah law. Having provided a substantial and useable justification for the ban, however, Abba-Mari never heard back from Barcelona concerning Sefer ha-Yare'ah. He was later informed that the elderly Ibn Adret had fallen ill. At the behest of his friend Jacob de Bilqieri, brother to the late Todros, Abba-Mari wrote once more to Ibn Adret in early March of 1305, after some eight months of silence between the two communities. ${ }^{32}$ With some resignation, he asked whether, after all, "the kid that I sent has grown horns with which to gore Satan"-whether, that is, Sefer ha-Yare'ah had had any positive impact upon the passage of a ban in Barcelona. ${ }^{33}$

Though the pamphlet's direct impact remains unknown, this inquiry restarted the campaign, leading to the passage of the Barcelona ban and a significant push for legislation in Montpellier as well. After some deliberation about the text of the Montpellier ban, Ibn Adret enthusiastically approved a draft text, instructing Abba-Mari to read it—loudly, he specifies—in the synagogue on the following Shabbat, which, not insignificantly, happened to be the somber fast of Tish'ah be-Av, commemorating the dual destruction of the Temple. ${ }^{34}$ The public reading of the approved Montpellier ban text never happened: at this advanced stage of the ban discussion, its opponents, realizing that legislation was imminent in both Barcelona and Montpellier, levied an excommunication ban of their own. ${ }^{35}$ This was a serious charge that, once promulgated, had to be dealt with. Abba-Mari did so through a campaign of letters. First, he

$32 \quad$ MQp 6o, p. 131/MQd 79, p. 665, l. 1.

33 MQp 6o, p. 132 / MQd 79, p. 667, ll. 22-23.

34 Abba-Mari merely refers to it as the Shabbat of Parashat Ve-'Eleh ha-Devarim 'Asher Dibber Mosheh, i.e., Deut. 1:1, in Parashat Devarim, usually read mid-summer, but in 1305 apparently falling on Tish'ah b’Av: see A. S. Halkin, "Why Was Levi Ben Hayyim Hounded?" Proceedings of the American Academy for Jewish Research 34 (1966): 65-76, who follows Eduard Mahler's Handbuch der jüdischen Chronologie (Leipzig, 1916) (MQp 71, p. 141 / MQd 90, p. 699, ll. 14-15). Whether or not this was intended to be a statement or was merely a coincidence is uncertain.

35 The sources are conflicted about the nature of this counter-ban, often referred to in the scholarly literature as "the 'Adrabbah," a term used by Simon b. Joseph (En Duran de Lunel) but not Abba-Mari, who reserved "Adrabbah" for his own draft of a ban cancelling the counter-ban of his opponents (i.e., a counter-counter-ban). According to Simon, their opponents' counter-ban was an excommunication of those who attempted to limit the study of philosophy, effectively the inverse of the Barcelona ban. According to Abba-Mari, however, the counter-ban was a different kind of ban completely. It was not only a potential excommunication, like the initial proposed measure which would, going forward, excommunicate anyone who were to study philosophy before attaining the age of twentyfive, or who teaches it to someone under that age. 
drafted a counter-ban to the order of excommunication, for which he found numerous supporters. ${ }^{36}$ Six of them composed and circulated their own letter of support for the excommunicated individuals. ${ }^{37}$ Abba-Mari also turned to Ibn Adret for advice on the validity of the order of excommunication, whereupon the Barcelona beit din officially invalidated the excommunications. ${ }^{38}$ Abba-Mari continued circulating formal letters updating the major Occitan communities about his efforts and appears to have come close to holding a formal vote on the ban in Montpellier. ${ }^{39}$

On the ground in Montpellier and Barcelona, where the majority of the Minhat Qena'ot letters originate, the extant sources describe the door-to-door solicitation of support that took place within the upper classes of these communities, much like what Jacob de Bilqieri had described about his activities throughout Occitania. These interactions were personal affairs, pressuring otherwise uninterested individuals to support one or the other side. The strident lobbying of the groups' spokesmen for or against the ban, then, did not represent the varied and often moderate views held by their members. The personal nature of the debate tactics is evident in the fact that relatively many of the men named in Minhat Qena'ot not infrequently changed allegiances, either out of convenience or because they evidently felt pressured to first support a position they did not actually favor. ${ }^{40}$

$3^{6}$ MQp 73, p. 143 / MQd 92, p. 703, ll. 32-35. This is the document to which Abba-Mari refers as "the 'Adrabbah." He seems to have found numerous supporters for his 'Adrabbah: he reports, "those who [initially] signed the document of the 'Adrabbah in our favor number more than seventy, and presently the number has risen to over a hundred" (MQp 73, p. 143 / MQd 92, p. 703, ll. 34-35).

37 MQp 78, pp. 144-51 / MQd 97, pp. 707-19.

38 MQp 81(b), p. 154 / MQd 102, pp. 739-740; MQp 82, pp. 154-6 / MQd 103, pp. 740-5; MQp 83, pp. 156-7 / MQd 104, pp. 746-51; MQp 93, pp. 172-3 / MQd 113, pp. 804-9; and MQp 99, p. 178 / MQd 119, pp. 832-5.

39 The exact procedure for such a vote in the early fourteenth century is not known, but seems to have involved the consent (in the so form of signature) of a plurality of the community's leadership. This not appear to be a legal procedure undertaken in the beit din (rabbinical court).

40 Moshe Halbertal emphasizes this point as well; see Concealment and Revelation: Esotericism in Jewish Thought and Its Philosophical Implications, trans. Jackie Feldman (Princeton, N.J.: Princeton University Press, 2007), 188, n. 12 and Between Torah and Wisdom: Menahem ha-Me'iri and the Maimonidean Halakhists in Provence [Hebrew] (Jerusalem: Magnes, 200o), 174. Halbertal cites Jacob b. Makhir, Isaac b. Judah de Lattes, and Shelemiah de Lunel as exemplars of ambivalence and side-switching. Shelemiah later became one of the signatories of the circulatory letter advocating for the 'Adrabbah (the counter to ban opponents' counter-ban) along with Abba-Mari: MQp 78, p. 151 / MQd 97, p. 712, l. 149 . 
Some made their public entrance into the debate by affixing their names to a letter written against the ban, only to regret their affiliation and beg the forgiveness of Ibn Adret or Abba-Mari. In the headnote introducing a letter by Ibn Adret, Abba-Mari reports that Ibn Adret informed him that "one leading aristocrat who signed the letter of the opposition (ketav ha-mitnagdim ${ }^{41}$ regretted giving that signature (nitharet min ha-hatimah ha-hi') and sent his apology to him [Ibn Adret]." ${ }^{22}$ Even more interesting is Abba-Mari's report about Samuel b. Reuben of Béziers (the cousin of Levi b. Abraham, who was, earlier in the controversy, accused of heresy):

He sent his letter to the rabbi [Ibn Adret], may God keep him, to apologize that he is found as a signatory to the letter of the opposition, for he had unintentionally transgressed (shogeg) and erred. This occurred because they [the ban opponents] came to his home early in the morning when he was drowsy. ${ }^{43}$

In other words, Samuel claims that he was ambushed by ban opponents when he was barely awake and signed without intending to assent to their position. Another prominent example is Qalonymos ha-Nasi b. Todros of Narbonne, who initially supported opponents of the ban, transferred his allegiance to its proponents. ${ }^{44}$ Abba-Mari had been surprised to learn that Qalonymos ha-Nasi had written words of disfavor about him in a letter to the Montpellier qahal (referred to but not preserved in Minhat Qena'ot). "We sat [i.e., studied] together in the house of our brother Meshullam; between us we knew what was right!" Abba-Mari writes back. ${ }^{45}$ It may be that Abba-Mari overreacted, since Qalonymos, in his response, notes that he merely wrote a few hasty lines to the ban opponents while en route to Béziers; but in any case, Qalonymos apologizes and pledges his support for the ban.

The opposite situation also occurred, in which an individual signed a public letter on behalf of ban proponents but then decided to support their opponents.

\footnotetext{
41 This is almost certainly the letter of the Montpellier rationalists, MQp 24, pp. 66-8 / MQd 43, pp. 431-440.

42 MQp 49, p. 104 / MQd 68, pp. 575-576, ll. 2-4. Interestingly, Abba-Mari directly quotes a line from this unnamed Montpellier aristocrat's letter in the headnote (ll. 4-6, written in the first person), which is not otherwise preserved.

43 MQp 41, p. 89 / MQd 6o, p. 524, ll. 1-4.

44 MQp 57, p. 121 / MQd 76, pp. 634-636. In addition, during this period of the exchange, Ibn Adret informed Abba-Mari of another Montpellier gentleman who turned to him apologetically, declaring his support for the ban (MQp 49, p. 104 / MQd 68, pp. 575-576, ll. 2-7. MQp 56, p. 120 / MQd 75, p. 632, ll. 6-7.
} 
Isaac b. Judah de Lattes was such a case. ${ }^{46}$ Lattes was tapped by Ibn Adret to serve as intermediary and peacemaker in the imbroglio between Abba-Mari and Shelemiah de Lunel, discussed in further detail below. Presumably, Lattes was viewed by Ibn Adret as a natural ally and resource, and Abba-Mari professes surprise upon hearing that Lattes wrote a letter "going the way of the opposition in full force, shedding blood of war in peacetime." ${ }^{7}$ Abba-Mari was then informed that "after he [Lattes] signed the letter affixed with our signatures, he signed on behalf of the opposition." 48 Similarly, Saul b. Solomon and Judah b. Moses b. Isaac, two signatories of Abba-Mari's hastily-written missive to Barcelona intending to obviate a damaging letter already dispatched by his opponents, are later found as signatories to a letter of the kat ha-mitnagdim. ${ }^{49}$

Still others were reluctant to actively lend their support to the ban proponents, but came around to it, apologizing for their hesitance. ${ }^{50}$ Abba-Mari was convinced that Jacob b. Makhir, the consummate representative of the Occitan rationalist tradition, was not initially against the ban but was swayed by his cousin Judah b. Moses Ibn Tibbon. ${ }^{51}$ That Abba-Mari could sensibly consider the scion of a founding family of the Occitan rationalist tradition as a potential ally is a strong indication that the lines between ban opponents and proponents

46 Isaac b. Judah is not to be confused with his famous grandson, Isaac b. Jacob (de) Lattes, author of Kiryat Sefer, an elaborate shalshelet ha-qabbalah and enumeration of the 613 commandments whose first section, entitled Sha'arei Sion, includes much valuable citations of important Occitan figures. Isaac b. Judah is known to have written astronomic and scientific treatises as well as commentaries on the Talmud; see Isaac Alteras, "Jewish Physicians in Southern France during the 13th and 14th Centuries," Jewish Quarterly Review 68 (1978): 209-23 at 219.

$47 \quad$ MQp 36, p. 8 o / MQd 55, p. 492, ll. 7-8.

48 MQp 36, p. 8o / MQd 55, p. 492, ll. 9-10.

49 Saul and Judah first appear as two of the twenty-five signatories to Abba-Mari's letter, MQp 23, p. 66 / MQd 41/42, p. 430, l. 64 and l. 65 (there are some significant variants in the signatories to this letter among the manuscripts, but Saul and Judah are consistently present); later, theirs are among the five preserved signatures to a letter Abba-Mari describes as tofes ketav hakhmei Mont Peshliyer mi-kat ha-mitnagdim le-nikhbadei qahal ha-qodesh she-be-Barșelonah, MQd *122, p. 853, l. 108 and l. 109 (but note l. 109, which states that numerous other signatures existed on the version being copied: ve-rabim).

$5^{\circ}$ See, for example, the letters of Qalonymos ha-Nasi b. Todros of Narbonne (MQp 57, p. 121 / MQd 76, pp. 634-636) and Moses b. Isaac ha-Levi (N'Escapet Melit) (MQp 84, pp. 157-16o / MQd 105, pp. 752-761, and see especially ll. 90-92).

51 MQp 21, p. 62 / MQd 39, p. 416, l. 30-35; and MQp 26, p. 70 / MQd 45, p. 445, ll. 11-20. Little is known about Judah, the son of Moses Ibn Tibbon and grandson of Samuel; Judah's brother Samuel and sister Bella are known from their participation in a lawsuit recorded in a responsum by Ibn Adret, published by Adolf Neubauer in Revue des études juives 12 (1886). 
are not easily drawn. ${ }^{52}$ In fact, Menahem ha-Me'iri (Don Vidal Solomon, 12491316) explicitly professed to ban proponents that he "rejoiced ... and praised you greatly" upon hearing that they were restricting sensitive knowledge to a controlled transmission path, becoming dismayed only when he realized the mechanism of doing so was a general ban. ${ }^{53}$

Moreover, Shelemiah, the same man active in staging the public readings of Anatoli, had initially supported the ban-and would eventually be excommunicated by ban opponents for re-joining the pro-ban faction. At the time that Shelemiah and Abba-Mari quarreled publicly, Ibn Adret assumed that Shelemiah was a ban proponent and that the disagreement was an internal one within his ranks. ${ }^{54}$ In an attempt to quiet the argument, Ibn Adret wrote directly to Shelemiah, sending him a typically equivocal letter, which closes by asking Shelemiah to oversee the effort to institute the ban in his community. He assures Shelemiah deferentially, "It never occurred to us to adjudicate these matters in our own courts," adding, "Your etiquette (musar) is not lacking, and where there is etiquette there is wisdom," he writes." ${ }^{55} \mathrm{He}$ is not reticent in praising Shelemiah, nor in reprimanding Abba-Mari for allowing the disharmony between him and Shelemiah to spiral out of control; Ibn Adret placed the blame for the quarrel, it seems, on Abba-Mari. Ultimately, he was to prevail, as Shelemiah was among the five individuals named in the "counter-ban" levied by the pro-rationalist faction. ${ }^{56}$

52 Moshe Halbertal takes Abba-Mari at his word, assuming that Jacob b. Makhir was initially sympathetic to the traditionalists (Between Torah and Wisdom, 174).

53 Preserved in Simon b. Joseph's Hoshen ha-Mishpat, ed. David Kaufmann, in Jubelschrift zum neunzigsten Geburtstag des Dr. L. Zunz, (Berlin: Louis Gerschel, 1884), Heb. sec. 150. On ha-Meiri's initial, ideologically-supportive stance, see Israel Zinberg, A History ofJewish Literature, Volume Three: The Struggle of Mysticism and Tradition Against Philosophical Rationalism, translated by Bernard Martin (Philadelphia: Jewish Publication Society, 1972), 90-91; and Moshe Halbertal, Between Torah and Wisdom, 170-1.

54 The events of the quarrel are recorded in a textually complex six-letter exchange, as AbbaMari notes in the headnote to MQp 33, p. 78 / MQd 52.1, p. 470, ll. 1-8. This Shelemiah/ Solomon de Lunel is probably to be identified with the Solomon b. Isaac de Lunel attested in an archival document which records that he, among several others, had been commissioned to collect taxes levied by Philip IV of France in 1286 on Jews living in the jurisdiction of the seneschal of Carcassonne (Gustave Saige, Les Juifs du Languedoc antérieurement au quatorzième siècle [Paris: Picard, 1881; Reprint, Farnborough UK: Gregg, 1971], 114; and Heinrich Gross, Gallia Judaica [Paris: L. Cerf, 1897; Reprint, with supplementary material by Simon Schwartzfuchs, Philo Press, 1969], 288). Like Ben Makhir, Shelemiah was likely a relative of Abba-Mari's, adding perhaps to the anxiety engendered by the discord between them.

55 MQp 3o, p. 76 / MQd 49, p. 464, ll. 37-38 and p. 465, l. 48.

56 The five named individuals who have been excommunicated are reported in a letter signed by six of Abba-Mari's supporters, MQp 78, p. $15^{\circ}$ / MQd 97, p. 416, ll. 109-112. 
Ibn Adret was not the only one concerned by the rift between Abba-Mari and Shelemiah; soon after, the acrimony between proponents and opponents of the ban, represented by the feuding men, would become the subject of discussion in all three communities (Barcelona, Perpignan, and Montpellier), decisively establishing the controversy as a public affair. Abba-Mari's relative, Moses b. Samuel b. Asher, appealed to Profiat Gracian (Samuel Hen de Béziers) in Perpignan and Isaac Lattes in Montpellier to bring Abba-Mari and Shelemiah to a reconciliation. Abba-Mari, Ibn Adret, and other supporters of a ban found themselves in a defensive position. Shelemiah, perhaps by virtue of his status as a nikhbad, was able to garner a great deal of support, as Moses b. Samuel b. Asher notes in a letter to Abba-Mari. ${ }^{57}$ Lattes was similarly unmoved by the appeals despite his earlier gestures of support for the ban, and instead gave his allegiance to the anti-ban party. The Barcelona nikhbadim had been blindsided by the strength of the opposition of Ben Makhir, Shelemiah, Lattes and others, having been led by Abba-Mari to believe that Montpellier was far more united in favor of philosophical study than it in fact was.

Thus the real effect of the ban proposal was to create factional groupings based on not so much on ideological positions as on social and political pressures internal to the community. This situation is reflected in the various words used in Minhat Qena'ot to describe these factions, including kitot, 'agudot, and 'edot. Abba-Mari initially refers to his opponents as "the opposing faction" (kat ha-mitnagdim).${ }^{58}$ Later, he goes so far as to call the opposition ha-kat ha-Yevanit, "the Greek faction."59 Rarely are they referred to as "philosophers," that is, rationalists, as in Abba-Mari's depiction of his opponents in the introduction to his work as "Ziphites who holler and bray, wise philosophizers in their own eyes" (based upon 1 Samuel 26:1, in which the residents of Ziph betray David, who is hiding in their territory, to Saul). ${ }^{60}$

The counter-ban would also excommunicate "any man who would prevent his son from studying physics and metaphysics (hokhmat ha-teva've-ha-'Elohut) and the foreign wisdom (hokhmat ha-'umot) even if he be less than twenty-five years of age" (MQp 73, p. 143 / MQd 92, p. 701, ll. 6-7).

$57 \quad$ MQp 38, p. 83 / MQd 57, p. 503, ll. 30-32.

$58 \quad$ MQp 23, p. $64 /$ MQd 41/42, p. 425, l. 1.

59 MQp 5, p. 30 / MQd 23, p. 212, l. 19 (and note the textual variant). The ban proponents do not employ a particular term to describe their own party, although in one place Ibn Adret uses the word 'edah to describe his own group: MQp 14, p. $5^{\circ}$ / MQd 32, p. 376, l. 28. Abba-Mari wrote to his associate Moses b. Isaac b. Asher in Perpignan that he contacted Ibn Adret in hopes that he would be able to form an 'agudah (union) to rein in the problematic parties: MQp 19, p. 59 / MQd 37, p. 408, 1. 48-49.

6o $\quad$ Based upon 1 Samuel 26:1, in which the residents of Ziph betray David, who is hiding in their territory, to Saul. MQp Introduction, p. 3 / MQd Introduction, p. 267, 1. 33. 
The political rather than ideological nature of factional grouping is evident in Moses b. Samuel b. Asher's report from Perpignan, the most detailed description of group formation in Minhat Qena'ot:

When a few members of our community saw the letters circulating in our city - it is not possible to copy them here, so as not to arouse the suspicion that I am associated with their content, which I am not - they divided into three factions (kitot). One faction says: Who is one man, [even] one among thousands who has been chosen as the preeminent in this generation, to judge the way for all people or communities? ... Another faction says: How is it that they do not have criteria for discerning a servant of God from one who does not worship Him? ... Another faction says: "holy, holy, [holy,]": they are saying the truth, and their view of the Torah is correct, and the true Torah is on their tongues. ${ }^{61}$

As Moses describes it, only some among the Perpignan aristocracy were troubled by the activities of the ban proponents; but those who were appear to have taken the matter quite seriously. The first group is affronted by the idea that any one person, even someone with the high stature of Ibn Adret, should legislate for the kelal, i.e., on the supra-communal level. The second group seems primarily critical of the lack of clarity on what constitutes transgression; they suggest that the implications of a ban are sufficiently grave that such accusations need greater scrutiny. The third group, in contrast to the first two, is strongly in support of anti-rationalist measures. ${ }^{62}$ These three groups essentially belong to only two factions, one that is against limiting the study of non-Jewish philosophical texts and one in favor of it. The constituents of the former may have different reasons for taking the position that they claim, as Moses is at pains to point out, but both are critical of the ban and the ideas behind it.

Although there was great efficacy in forcing a response for or against the ban proposal — for opponents as well as proponents — the divisiveness in itself was a matter of great concern to all. This has a basis in the talmudic principle of $l o^{\prime}$ titgodedu, which, according to tannaitic interpretation, recommended

61 MQp 18, p. 57 / MQd 36, p. 401-2, ll. 30-37.

62 The antecedent is unclear, but the letters to which these three groups are reacting were apparently those written by Ibn Adret and Bonafos Vidal (see MQp 18, p. 57 / MQd 36 p. 401, ll. 27-28). These are likely MQp 10, 11, 13, and 14 / MQd 28, 29, 31, and 32 (and perhaps also MQp 15, 16, and 17 / MQd 33, 34, and 35). 
against the formation of factions and in favor of a united community. ${ }^{63}$ AbbaMari was explicitly criticized for causing such divisiveness by members of the Perpignan qahal as well as by those of his own community in Montpellier, and he sent letters of apology concerning both. ${ }^{64}$ Abba-Mari makes sure to note that he took pains to notify all prominent members of the community that he was convening a meeting, but few showed up. Those who did attend were nearly unanimous in agreeing that a ban was necessary, he emphasizes. Only when Jacob b. Makhir stepped in did two factions form; and even here, AbbaMari says only, "He [Ben Makhir] enlarged upon his viewpoints as he wished until [those he swayed] almost became a faction." ${ }^{65}$ The formation of factions was at once problematic and desirable for those concerned about the impact of philosophy on Jewish intellectual life.

Minhat Qena'ot illustrates that an intellectual debate could have a real impact upon a community. In Montpellier, those on both sides of the debate were active in convening meetings, writing and conveying letters, speaking with others, and traveling to petition. Even though many of those who participated in the debate did so equivocally, they seemingly could not avoid being mobilized for one side or the other. The Maimonidean controversy of 1304-1306 was ended prematurely by the French expulsions, but remained alive enough that Abba-Mari considered it important and effective to compile and contextualize the letters from the event. This was not an esoteric discussion but a pragmatic debate about the education of communal leaders and the access that laymen would have to material considered potentially harmful to the functioning of the community.

63 This is an interpretation of Deut. 14:1, also understood in context of prohibiting self-mutilation. The locus of the rabbinic reading (lo'ta'asu 'agudot 'agudot) is Sifrei Devarim, 96, and is instrumental to the argument in Yevamot $13 \mathrm{~b}$.

64 Apology for the mahloget in Perpignan: MQp 19, pp. 58-59 / MQd 37, pp. 404-8; apology for the mahloqet in Montpellier: MQp 25, 68-70 / MQd 44, pp. 440-444 and MQp 26, pp. 70-71 / MQd 45, pp. 444-8.

65 MQd 21, p. 63 / MQd 39, p. 418, l. 60 (emphasis mine). 